\title{
INOVA
}

Working Paper

\# 597

2015

\section{Debt, information asymmetry and bankers on board}

João Amaro de Matos João Mergulhão
NOVA

School

of Business

\& Economics

Shaping

powerful

minds

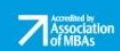




\title{
Debt, information asymmetry and bankers on board
}

\section{João Amaro de Matos}

Nova School of Business and Economics

Sao Paulo Business School, FGV

\section{João Mergulhão}

Sao Paulo School of Economics, FGV

\begin{abstract}
:
We provide evidence that the presence of bankers in the board of directors reduce information asymmetry between credit markets and firms. We show that the impact of the presence of bankers on leverage is driven by firms with low level of debt. This effect is amplified the more connected the bankers are to the corporate world. Additionally the results are more pronounced for less transparent firms. Our findings suggest that the connectedness of bankers play a key role in reducing information asymmetry.
\end{abstract}

JEL classification numbers: G32, G21, D82, L14

Keywords: information asymmetry, debt level, social networks, corporate boards, bankers 


\section{Introduction}

There is evidence that bankers in the board of firms impact positively the capacity to increase their debt level (e.g. Engelberg, Gao, and Parsons (2012) and Ferreira and Matos (2012)). In this paper we provide evidence that this leverage impact is essentially driven by low debt firms. We also suggest that the role of bankers as debt facilitators can be better understood by exploring their connectedness. In fact we provide further evidence that the impact of bankers is amplified the more connected they are to the corporate world, and also that this amplification effect is larger for firms with low level of debt. Finally we show that these results are stronger for less transparent firms, which is consistent with the idea that connected bankers reduce information asymmetry.

Using a sample of non-financial U.S firms (S\&P 1500 constituents), we find that the presence of a banker increases the leverage ratio by $22,6 \%$. The positive average treatment effect is consistent with previous literature results.

We then test if the connectedness of bankers impact on the debt level. We measure the connectedness of each of the board members using board membership data. In contrast with the board interlocks literature, this approach allows to distinguishing the connectedness of dierent directors, thus identifying the role of individual bankers in the information transmission mechanism. Our results indicate that the impact of bankers connectedness on the debt level is also positive, on average, and robust to different measures of connectedness commonly used in the social networks literature.

Additionally we build an information asymmetry index for each firm, following Gomes and Phillips (2012), and check how the previous result differs across various levels of transparency. Our findings indicate that the impact of bankers connectedness on the debt level is reduced when information asymmetry problems are less severe. These results are consistent with the interpretation that connected bankers contribute more to the reduction of information asymmetry and that this contribution is more important for opaque firms.

Finally, we use quantile regressions to distinguish both effects (presence and connectedness of bankers) for firms with different levels of leverage. We show that, for firms with relatively low levels of debt, both the presence and the connectedness of bankers will im- 
pact positively on the debt level. These effects are not present when analyzing firms with relatively high levels of debt. Our interpretation is that bankers contribute to the reduction of information asymmetry, transmitting to the market their perception of the debt capacity use. Again, these results are robust to the different measures of connectedness used.

We classify two individuals as connected if they sit on a given board in the same year. By construction the number of directors in each board will automatically impact the connectedness measures. Also, the larger the board, the more likely it is to find a banker in the board. We thus address the endogeneity concerns using board size as an instrument, since board size per se does not affect the debt level of a rm.

An extensive literature ${ }^{1}$ provides evidence that the presence of bankers in companies boards impacts positively the capacity of these firms to increase their debt level. Among others, Engelberg, Gao, and Parsons (2012) and Ferreira and Matos (2012) argue that the effect of bankers' presence in the board of borrower firms is the development of a special lending relationship that facilitates the access to the credit market.

The relations between banks and corporations are known to reduce informational asymmetries and thus lowering the financing costs Diamond (1984). In particular bankerdirectors (bankers who sit simultaneously on the board of directors of a bank and of nonfinancial firms) provide financial expertise (Mace, 1971; Lorsch and Maciver, 1989) and monitor effectively the management of firms, lowering the costs of funds (James, 1987; Williamson, 1988; Berger and Udell, 1995; Kroszner and Strahan, 2001). Booth and Deli (1999), Kroszner and Strahan (2001), and Byrd and Mizruchi (2005) show a positive correlation between firms' capital structure and the presence of unaffiliated banker-directors (who do not have direct conflict of interest in the capital structure's decision). Krakaw and Zenner (1998) show evidence of negative price reaction to announcement of loan renewals involving a bank represented on the firm's board, reflecting the fact that creditors on the board have an informational advantage over outside creditors. Using an international sample of firms with bankers on board, Ferreira and Matos (2012) provide evidence that banks extract informational rents from the firms, by charging higher loan rates in favorable market

\footnotetext{
${ }^{1}$ See Petersen and Rajan (1994),Berger and Udell (1995), Byrd and Mizruchi (2005), Ciamarra (2006), Engelberg, Gao, and Parsons (2012), and Ferreira and Matos (2012).
} 
conditions. Güner, Malmendier, and Tate (2008) also shows that the presence of financial experts on the board affect corporate decisions, although not always in the best interest of shareholders.

The role of networks connecting board members has been exploited in many different corporate finance contexts (e.g. Cohen, Frazzini, and Malloy, 2008; Goldman, Rocholl, and So, 2009; Bouwman and Xuan, 2010; Bouwman, 2011; Stuart and Yim, 2010; Fracassi, 2012; Chiu, Teoh, and Tian, 2013). Regarding the relation of firms with credit markets, Chuluun, Prevost, and Puthenpurackal (2014) provides evidence that, on average, the connectedness of the firm (as measured by board interlocks) is negatively related with the cost of debt and that this effect is stronger in the presence of higher information asymmetry. By assuming that networks facilitate the information dissemination mechanism as argued by Chuluun, Prevost, and Puthenpurackal (2014), following Nohria (1992), Burt (1997), and Nahapiet and Ghoshal (1998), using board interlocks instead of individual connections will not allow for understanding the role of individual bankers in the process.

Our work contributes to this discussion by building on two critical aspects. First, the connectedness measures in our paper are based on the connectedness of each of the members of the board, allowing to identifying the role of individuals in the information transmission mechanism. Our technology allows us to further refine the results of Chuluun, Prevost, and Puthenpurackal (2014) by focusing on the role of specific bankers who sit on the board of firms, linking to the spirit of Byrd and Mizruchi (2005),Engelberg, Gao, and Parsons (2012), and Ferreira and Matos (2012). Additionally, we are able to show that their reported impact of board connectedness in the leverage of firms is mostly driven by banker-directors' connectedness.

Second, and most importantly, we distinguish the average positive impact of bankers in debt level for firms with different levels of leverage. We provide robust evidence that this is true for firms with relatively low levels of debt but it is not true for over-levered firms. We further provide evidence to corroborate the interpretation that bankers sitting in the board of firms help reducing information asymmetries in the credit market.

This paper is organized as follows. In Section 2 we hypothesize how the presence (and 
the centrality) of a banker-director may affect the capital structure decisions. In Section 3 we describe the methodology and the data, addressing firstly, the directors' network and the centrality measures used to classify the influential role of bankers and secondly, the estimation procedures used to correct for a possible endogeneity bias, and finally we describe our databases. In Section 4 we present the results. The main conclusions are summarized in Section 5.

\section{The role of bankers}

Podolny (1994) points that social relationships between market agents may prevent market failure due to uncertainty and information asymmetry. Additionally, networks of social relationships can be shown to allow information gathering from non-directly connected sources, playing a crucial role in screening and selecting the relevant pieces of information (Burt, 1997), and lowering information-gathering costs (Nahapiet and Ghoshal, 1998).

In the same way, we should expect the social relationships of the directors of a firm to play a role in information transmission, reducing the information asymmetry between agents in the market. Shane and Cable (2002) show the importance of social ties in obtaining venture capital.

Our proposal is to use the network of the boards and directors as a proxy for the real social network of market agents. This means that the network we construct only has partial information of the professional relationships between agents, excluding all other relationships, both professional (all non-board related connections) or private (family/friendship ties or common memberships of Universities, clubs). Also, we can only observe that two directors sit in the same board at a particular time and assume that those two must know each other and are, therefore, directly connected.

Using social network analysis and suitable centrality measures, we infer the influence of each director. In particular, we are interested in the role of bankers-directors in the information flow, and its impact on the reduction of information asymmetries and, as a consequence, its impact on the firm's access to the credit market. If the social network of directors is a good proxy for the real life social network, we should then expect that the 
presence of a banker on the board of firm may reduce the information asymmetry between firm and lenders which, in turn, allows the firm to increase its leverage. Specifically, we test the following hypothesis:

Hypothesis 1 On average, the presence of a banker on the board increases the leverage of a firm.

Byrd and Mizruchi (2005) have already tested for hypothesis 1, i.e. they tested for the mere presence of bankers in boards. However, no study has evaluated the role of bankerdirectors in the information transmission mechanism. If it is true that bankers are important in reducing information asymmetry, then the more connected a banker is, the more effective she will be in that role. Note that we do not assume that the banker is sharing insider information or acting in any other illegal way. It suffices to interpret the banker's role in the information transmission mechanism as in Burt (1997), where the network is used as a filter for the relevant pieces of information: when the market analyses all pieces of available information, it will give more weight to information coming from more influential sources than others. Again, assuming that a reduction in the information asymmetry facilitates the access to the credit markets, we test for the following hypothesis:

Hypothesis 2 On average, the more connected a banker-director, the higher the leverage of a firm.

Other factors than connected bankers can contribute to disseminate information and hence, the level of information asymmetry (or opacity) does not depend only on the presence of bankers. Bankers may be invited to sit on boards of more or less opaque firms. Our assumption is that the higher the information asymmetry, the more important is the role of a connected banker for the information transmission mechanism. This same idea is corroborated in the financial literature in different contexts (e.g. Butler, 2007; Mansi, Maxwell, and Miller, 2010; Engelberg, Gao, and Parsons, 2012; Chuluun, Prevost, and Puthenpurackal, 2014). If the effect of the presence of a banker-director on the firm's level of debt is in fact due to a reduction in the information asymmetry, then one should expect this effect to be higher the more opaque the firm and the more connected the banker-director. We 
specify this hypothesis as:

Hypothesis 3 The higher the level of information asymmetry, the larger the average impact of the connectedness of a banker on the leverage of a firm.

It is also natural to assume that the way bankers reduce information asymmetry will strongly differ according to the debt level of firms. A banker sitting in the board of a firm with a relatively low level of debt, will perceive the probability that such firm is below its optimal debt capacity as very high. In that case, the bankers' role is to facilitate the dissemination of that message to the market, favouring both the firm and potential lenders. On the contrary, if a banker is sitting in the board of a firm with a relatively high level of debt, the probability of bankruptcy may be perceived as too high and the banker's role should be to discourage further debt. We thus formalize our hypothesis as:

Hypothesis 4 For firms with relatively low levels of debt, bankers facilitate the increase of leverage level, whereas for high-levered firms this is not true.

Finally we combine the assumptions in Hypothesis 2 and 4 into a different observable assumption. Hypothesis 2 states that the more connected a banker-director is, the larger is her impact on the debt level of a firm. Hypothesis 4 says that the likelihood of debt increase is larger the lower the initial value of debt. Thus, we assume that the effect described in the latter must be amplified by the banker's level of connectedness. Our final hypothesis reads:

Hypothesis 5 For firms with relatively low (high) levels of debt, the more connected the bankers are, the larger is their capacity to facilitate (impede) debt increase.

\section{Network Construction and Centrality Measures}

Information does not flow between firms, but rather through the individuals placed in different firms. Therefore, we opt to construct the network of relationships between directors instead of pure board interlocks, as exemplified below. In Figure 1, there are three firms 
and eight directors. Note that there are no connections between directors. Directors are linked only to firms where they sit on the board 2 .

\section{INSERT FIGURE 1 HERE}

Figure 2 is the result projecting the network in Figure 1 onto the space of directors. Each individual is linked to all others with whom he shares a board. However, a usual approach in the literature is to consider only the board interlocks. This dilutes the network characteristics relevant to information transmission. In the example above, the complex network of Figure 2 would be reduced to a simple network where firms $\mathrm{A}$ and $\mathrm{C}$ are connected to firm B.

\section{INSERT FIGURE 2 HERE}

Instead, using the network of directors, we are able to measure the role of each individual on the flow of information, by computing a connectedness measure for each individual on the network. We focus on three basic measures of connectedness commonly used in information flows / contagion analysis: degree, closeness and betweenness. These measures are also referred as centrality measures.

The degree of a vertex is the number of connections of a vertex with other vertices of the network. Within the directors' network it represents the number of directors with whom a particular individual is related to. A director with higher degree centrality knows more directors inside the network.

Closeness centrality (Sabidussi, 1966) is the inverse of the average distance from a particular vertex to every other vertex. Within the directors' network, it represents the average number of contacts that a director would have to make in order to reach any other director on the network ${ }^{3}$ A director with higher closeness centrality will need on average less intermediaries to reach any other director.

\footnotetext{
${ }^{2}$ This is a characteristic of affiliation networks, more generally referred to as 2 -mode network. These networks have two types of vertices and connections can only occur between vertices of different types.

${ }^{3}$ As there are directors which are isolated/separated from part of the network, the classical definition of closeness is not well defined. The solution for these cases, is to use the influential range of each director, i.e. to measure the centrality within the reachable component of the network (Lin, 1976) as a ratio of the total number of vertices
} 
Betweenness centrality (Freeman, 1977) may be interpreted as the probability that director $i$ is a vehicle of information transfer between director $k$ and director $j$, assuming that all shortest paths are equally likely to be used.

After computing the connectedness measures for each individual in the directors' network, we aggregate the latter at the firm level. As we are interested in the information role of bankers-directors, we only use the connectedness of banker-directors in the aggregation process: for each firm, the corresponding connectedness measure is the maximum value of the banker-director in the board. If there is no banker-director, the centrality measure is 0 . We proxy the informational role of the board through the maximum for two reasons. First, we assume that the determinant individual in the information distribution is the one who is more connected/influential. Second, the sum of centrality measures can be ambiguously interpreted. Figure 3 five demonstrates this procedure using the previous three firms example. Firm $\mathrm{C}$ now plays the role of a bank and, hence, Director 5 is a banker-director. Each director's centrality degree is shown in parentheses. The three directors of Firm 1 have degrees of 2, 2 and 4. However the degree centrality of Firm 1 will be 0 as it has no banker seating on the board. Firm 2 has a one banker on the board with degree 4 . Therefore the degree centrality of Firm 2 will be 4 . Had the Firm had a second banker on the board with connections to less than 4 other directors, the degree of Firm 2 would had still be 4 .

\section{INSERT FIGURE 3 HERE}

\section{Data}

Our network data is based on the Directors database provided by ISS (former RiskMetrics). The sample includes board information for S\&P1500 firms from 1996 to 2013 with data on more than 11000 directors/year. We consider that two directors are connected in a particular year if they sit in the same board during that year ${ }^{4}$ and compute the connectedness measures mentioned above for each individual/year.

Remaining variables are compiled using Compustat/CRSP. Our variable of debt level

\footnotetext{
${ }^{4}$ We only consider contemporaneous connections, although it can be argued that the social network is built throughout the years, accumulating connections.
} 
is the leverage ratio computed as the ratio of total interest bearing debt to the sum itself with market capitalization [Compustat items: $\left.(d l t t+d l c) /\left(d l t t+d l c+\left(p r c c_{-} f^{*} c s h o\right)\right)\right]$. We also include the usual controls:5: EBIT [Compustat item: $i b+x i n t+t x t]$ over total assets [Compustat item: at] as the profitability measure; the log of market-to-book ratio as growth opportunities measure [Compustat items: $\left.\ln \left(\left(d l t t+d l c+p s t k l+p r c f_{-} f^{*} c s h o\right) / a t\right)\right]$; the ratio of depreciation expenses [Compustat item: $d p$ ] to total assets, controlling for firms with less need for debt related tax shield; the logarithm of total assets as a measure of size; the ratio of fixed [Compustat item: ppegt] to total assets as a measure of asset tangibility; the ratio of R\&D expenditure [Compustat item: $x r d$ ] to total assets as a proxy for asset specificity 6. and the standard deviation of abnormal returns as a proxy for firm volatility. We also control for industry median and year fixed effects.

After merging the two databases, our sample includes 15426 firm-year observations. The descriptive statistics are presented in Table 1. Banker-directors are present in $26.7 \%$ of the firms.

\section{INSERT TABLE 1 HERE}

We build a proxy of firm opacity based on the method proposed by Gomes and Phillips (2012) (henceforth $I A m m$ ) which consists in averaging quintile rankings of individual information asymmetry proxies. As is Maskara and Mullineaux (2011), we include analysts forecast errors and dispersion of analyst opinions from $I \backslash B \backslash E \backslash S$, volatility of residual returns and firm age from CRSP 7 , Following the suggestion of Bharath, Pasquariello, and Wu (2009), we also rank the quintiles of the Amihud's (2002) illiquidity measure, the Amivest illiquidity ratio (Kerry Cooper, Groth, and Avera, 1985; Amihud, Mendelson, and Lauterbach, 1997), the fraction of proportional quoted and Rolls (1984) effective spread due to adverse selection for each stock. After merging with our sample, we have 12005 firm-year observations. Table 2 presents the descriptive statistics.

\section{INSERT TABLE 2 HERE}

\footnotetext{
${ }^{5}$ For a thorough review of the literature, see Frank and Goyal (2008)

${ }^{6}$ For firms not reporting R\&D expenses, this ratio is set to zero. We add a dummy variable to identify these cases

${ }^{7} \mathrm{We}$ do not compute the volatility of abnormal returns around earnings announcements
} 
We use board size as an instrument, where board size is the total number of directors on each board, measured by the number of directors listed in Riskmetrics. The larger the number of directors on the board, the higher the probability that one of the directors also sits at a bank. We do not expect the board size itself to impact directly on debt levels ratio of the firm, however there is a positive relationship between firm size and board size documented in the literature. Both Linck, Netter, and Yang (2008) and Boone, Field, Karpoff, and Raheja (2007) find evidence that the board size of firms increase with size and complexity of operations, where the former study focuses on young firms $(<10$ years since IPO) and the latter on the different characteristics of boards in small and large firms. This positive relationship between firm and board size is also present in our data. Nevertheless, when using the centrality measures under the IV approach, board size seems a good candidate for instrument as the centrality measures of the directors are, by construction, dependent of the original board size 8 . Therefore, larger boards will automatically increase the number of connections between the directors seating on those boards, independently of any boards interlocks.

\section{Results}

This section presents our results for the testing of the main hypothesis.

As for $\mathrm{H} 1$ and $\mathrm{H} 2$, the market debt ratio (MDR) of a firm, as defined in the former section, should be directly related to the presence and the connectedness of the bankerdirector. We thus generate a variable Banker $_{i, t}$ that in the case of $\mathrm{H} 1$ is associated to the presence of a banker-director, and in the case of $\mathrm{H} 2$ is associated to her degree of connectedness. In that sense the regression reads

$M D R_{i, t+1}=\delta$ Banker $_{i, t}+\boldsymbol{\beta}$ Controls $_{i, t}+\epsilon_{i, t}$,

where the dependent variable is the market leverage ratio, as defined in the previous section, Banker may denote either the presence of banker on the board (hypothesis 1)or one of

\footnotetext{
${ }^{8}$ We construct the network of directors, by projecting the original (2-mode) network, with boards and directors, onto a network of only directors, where directors are connected if they share the same board in the same year
} 
the three banker-director connectedness measures (hypothesis 2), and Controls include all control variables including year fixed effects, also defined in the previous section. The latter are winsorized at $1 \%$ level. The $\epsilon$ term may include firm fixed effects.

We need to correct for possible endogeneity bias when testing for our hypothesis that bankers-directors (and their centrality on the network) affect the debt level of a firm. The choice of board composition, and hence the presence and connectedness of the banker, may not be independent of the choice of the debt level. We use average treatment effects regression to estimate the average impact of the presence of a banker-director on debt level (hypothesis 1) and I.V. regressions to correct for possible endogeneity biases (hypothesis 2) 9

In order to test hypothesis 3 , we add an extra term, interacting the presence and the connectedness of the banker-directors with the Information Asymmetry index presented in the former section:

$M D R_{i, t+1}=\delta$ Banker $_{i, t}+\gamma_{0} \mathrm{IAmm}_{i, t}+\gamma_{1}$ Banker $_{i, t} \times \mathrm{IAmm}_{i, t}+\boldsymbol{\beta}$ Controls $_{i, t}+\epsilon_{i, t}$.

Hypothesis 4 and 5 require a quantile regression approach (Koenker and Basset, 1978; Koenker and Machado, 1999). We use the method proposed by Cattaneo (2010) which allows estimating treatment effects on different quantiles, dealing simultaneously with endogeneity and multi-dosage treatments.

\subsection{Average Effect of the presence of Banker-Directors}

We test hypothesis 1 by running the regression on (1) Table 3 presents the results for testing the average impact of the presence of banker-directors on the debt levels of firms.

The first column presents the results of the OLS regressions; the second column is a panel regression including firm fixed effects; the third column reports the result incorporating the average treatment effect that takes into account the endogeneity problem. As expected, this latter result retrieves what was found in Byrd and Mizruchi (2005) and Ciamarra (2006): the presence of banker-directors on boards increases, on average, the debt level of firms.

\footnotetext{
${ }^{9}$ Using I.V. with binary endogenous may lead to biases estimates of the parameters of interest (Imbens and Angrist, 1994; Angrist, Imbens, and Rubin, 1996)
} 
Notice that although in the OLS and the panel regression the sign of the average impact of a banker-director is negative, when the endogeneity is taken into account the sign reverts and becomes positive and significant.

\section{INSERT TABLE 3 HERE}

\subsection{Average Effect of the connectedness of Banker-Directors}

We test hypothesis 2 by running again the regression on equation (1), but now using the variable Banker as different measures of connectedness of the bankers sitting on the board. Table 4 presents the results for testing the average impact of banker-directors' connectedness on the debt levels of firms.

The first three columns present the results of the I.V. regressions on the connectedness measures, with year fixed effects, whereas the last three columns also incorporate firm fixed effects. As easily observed, in both cases the three measures of connectedness (Degree, Closeness and Betweenness) are positive and statistically significant.

In a similar vein of Chuluun, Prevost, and Puthenpurackal (2010) who find that the board connectedness impact negatively, on average, the cost of debt, our results indicate that connectedness of banker-directors impacts positively, on average, the debt level. As a robustness test of our results we compute the connectedness of boards excluding bankers and notice in table 5 that its impact on debt level is statistically insignificant ${ }^{10}$. In this sense our results suggest that the findings in Chuluun, Prevost, and Puthenpurackal (2010) are driven by the presence of bankers in the boards. Given the highly skewed distribution of connectedness, it is not enough to consider the mere presence of banker-director on the board. We show that on average, the higher the banker's connectedness, the stronger is his/her impact on the debt level of the firm., ceteris paribus.

\section{INSERT TABLE 5 HERE}

These effects are also economically significant. If we only consider the data with year

\footnotetext{
${ }^{10}$ This result holds for all connectedness measures except degree. The reason why this variable is less interesting for this purpose is that while it captures only direct connections for the individuals, both variables closeness and betweenness integrate connectedness information from the whole network. Thus, these last variables better capture the information flow within the network.
} 
effects and no fixed effects an increase of one standard deviation in any of the connectedness measures (i.e., degree, closeness or betweenness) is associated with an increase of 8.13, 9.72 and 11.13 percentage points of the market debt ratio, respectively. By including fixed effects, these numbers change into 6.65, 9.19 and 7.64 .

As explained previously, we use board size as instrument in all regressions. Unreported first stage results confirm the positive relation between board size and connectedness of banker-directors. In addition, the coefficients of the control variables are significant and have the expected sign.

\section{INSERT TABLE 4 HERE}

\subsection{Information asymmetry and Banker-Directors}

Our basic interpretation is that the presence of bankers in the board facilitates the communication with the market, and the more connected the banker is, the more effective that communication is in reducing information asymmetry. We thus assume that the impact of bankers in defining the debt level is larger for firms facing higher levels of information asymmetry, as in Hypothesis 3 . We test that hypothesis by considering the interaction of an aggregate index of information asymmetry proxies (as in Bharath, Pasquariello, and Wu, 2009; Maskara and Mullineaux, 2011; Gomes and Phillips, 2012) with (i) the presence of bankers in the board and (ii) several different measures of connectedness of these bankers.

From Table 6 we can see that the interaction with both the presence of bankers and with the different connectedness measures of these bankers are positive and significant, thus corroborating the hypothesis as stated.

\section{INSERT TABLE 6 HERE}

\subsection{Quantile regressions and bankers' presence}

We assume that a banker-director in a firm with a relatively low level of debt will perceive the probability of bankruptcy as very low. Alternatively, if the level of debt is relatively high, the probability of bankruptcy is perceived as high. Thus, the way bankers use their channels of communication to the market in order to reduce information asymmetry will 
differ according to the debt level of firms. For low debt levels the presence of bankers on the board will facilitate the increase of debt, whereas for high debt level the presence of bankers will make it harder to increase the debt level. This is the content of Hypothesis 4 .

In order to test this hypothesis, we use quantile regressions, as it allows us to focus on effects on a specific quantile - where low (high) quantiles represent relatively low (high) debt level firms - instead of on the average effect provided by the previous estimations. In particular, we compute the quantile treatment effects (Firpo, 2007; Cattaneo, 2010) taking into account the same endogeneity issue referred to in the previous sections. The results in Table7 represent the average treatment effect of the presence of a Banker per quantile. As we can see, for low quantiles including the median(i.e., firms with low level of debt) the effect is positive and statistically significant at $90 \%$ level. For higher quantiles, although this effect is not statistically distinguishable from zero, the impact is negative suggesting that the presence of bankers in the board tends to reduce firms' debt level.

These results are coherent with those presented in Byrd and Mizruchi (2005), who split their sample into high- and low-distressed firms, analysing for each subgroup its average behaviour. Although their results pointed to a similar interpretation, our quantile approach allows to analyse the different impact throughout the whole distribution of debt level.

\section{INSERT TABLE 7 HERE}

\subsection{Quantile regressions and bankers' connectedness}

Following the argument raised before, we assume that more connected banker-directors can be more effective in the dissemination of information, simply because they have more channels of information available to pass their message to the markets. In that sense, we would expect that the connectedness of bankers will amplify the effect described before. This what has been expressed as Hypothesis 5 .

In order to test this hypothesis, we again run a quantile regression to measure the separate impact of highly connected bankers from that of not so well connected bankers. We do so by estimating a multi-treatment effect quantile regression with two levels of treatment. We split the bankers in two groups: group 1 composed of weakly connected 
bankers (with respect to the median degree) and group 2 composed of highly connected bankers. The results are shown in Table 8 , indicating that for low levered firms the impact of well connected bankers is approximately twice as much as for low connected bankers. In the lowest quantile the presence of a highly connected banker increases debt by $1.5 \%$, whereas the presence of a low connected banker increases debt by only $0.6 \%$. In the next quantile the ratio is $1.7 \%$ to $0.9 \%$. In the median the ratio goes to $1.0 \%$ to $0.5 \%$ but these numbers are no longer statistically significant, as it is the case for higher quantiles (i.e. for firms with relatively higher levels of debt). Interestingly, although not significant, almost all the numbers for higher quantiles are negative, suggesting that the presence of highly connected bankers in the board tends to reduce firms' debt leve 11 .

\section{INSERT TABLE 8 HERE}

\footnotetext{
${ }^{11}$ We repeated the analysis for the different measures of connectedness and the results are qualitatively equivalent.
} 


\section{Conclusion}

There are two different classes of well-known results regarding the role of boards in the debt capacity of firms. The first result is that the presence of bankers help firms increasing debt. The second is that the leverage effect is more effective the more connected boards are. We contribute for the first result by showing that the presence of bankers has more impact the more connected they are. We contribute for the second result by showing that the impact of boards' connectedness is driven by the bankers' connectedness. Finally, we show that both effect are only relevant for firms with relatively low debt level.

Our findings suggest that firms can use connected bankers on the board in order to reduce information asymmetry. The presence of connected bankers is shown to increase on average the debt level of the US firms included in our sample. After correcting for endogeneity and controlling for other firms' characteristics, this effect is shown to be statistically significant. Moreover, this result is stronger the larger the connectedness of the banker on the directorship network. Our results seem to be robust with respect to the various measures of connectedness used throughout the paper.

In particular, the last part of these results suggests that bankers-directors have an essential role in the market dissemination of information. The more connected a banker is on the network, the more channels of communication she can use to transmit information, reducing information asymmetries between the firm and the credit market and consequently, allowing for higher levels of debt. This effect on the debt level is reduced for less opaque firms, sustaining our interpretation of the role of banker-directors as an information asymmetry reduction mechanism.

We provide evidence that both the presence and the connectedness of bankers increase the debt of low-leverage firms, while decrease the debt of high-leverage firms. These effects are shown to be statistically significant for the former but not for the latter. Once again, this justifies the mechanism of information asymmetry reduction described above. 


\section{References}

Amihud, Y, 2002, Illiquidity and stock returns: cross-section and time-series effects, $J$. Financ. Mark. 5, 31-56.

Amihud, Yakov, Haim Mendelson, and Beni Lauterbach, 1997, Market microstructure and securities values: Evidence from the Tel Aviv Stock Exchange, J. Financ. Econ. 45, $365-390$.

Angrist, Joshua D, Guido W Imbens, and Donald B Rubin, 1996, Identification of Causal Effects Using Instrumental Variables, J. Am. Stat. Assoc. 91, 444-455.

Berger, Allen N, and Gregory F Udell, 1995, Relationship Lending and Lines of Credit in Small Firm Finance, J. Bus. 68, 351-381.

Bharath, Sreedhar T., Paolo Pasquariello, and Guojun Wu, 2009, Does asymmetric information drive capital structure decisions, Rev. Financ. Stud. 22, 3211-3243.

Boone, A L, Laura Casares Field, Jonathan M Karpoff, and Charu G Raheja, 2007, The determinants of corporate board size and composition: An empirical analysis, J. Financ. Econ. 85, 66-101.

Booth, James R, and Daniel N Deli, 1999, On executives of financial institutions as outside directors, J. Corp. Financ. 5, 227-250.

Bouwman, C. H S, 2011, Corporate governance propagation through overlapping directors, Rev. Financ. Stud. 24, 2358-2394.

Bouwman, C. H. S., and Y. Xuan, 2010, Director overlap and firm financial policies, .

Burt, Ronald S, 1997, The contingent value of social capital, Adm. Sci. Q. 42, 339-365.

Butler, A. W., 2007, Distance Still Matters: Evidence from Municipal Bond Underwriting, Rev. Financ. Stud. 21, 763-784.

Byrd, D T, and M S Mizruchi, 2005, Bankers on the board and the debt ratio of firms, $J$. Corp. Financ. 11, 129-173.

Cattaneo, Matias D, 2010, Efficient semiparametric estimation of multi-valued treatment effects, J. Econom. 155, 138-154.

Chiu, Peng-Chia, Siew Hong Teoh, and Feng Tian, 2013, Board Interlocks and Earnings Management Contagion, Account. Rev. 88, 915-944.

Chuluun, Tuugi, Andrew Prevost, and John Puthenpurackal, 2014, Board Ties and the Cost of Corporate Debt, Financ. Manag. 43, 533-568.

Chuluun, Tuugi, Andrew K. Prevost, and John Puthenpurackal, 2010, Board Ties and the Cost of Corporate Debt, SSRN Electron. J.

Ciamarra, Elif Sisli, 2006, Monitoring by Affiliated Bankers on Board of Directors : Evidence from Corporate Financing Outcomes, Work. Pap.

Cohen, Lauren, Andrea Frazzini, and Christopher Malloy, 2008, The Small World of Investing: Board Connections and Mutual Fund Returns, J. Polit. Econ. 116, 951-979. 
Diamond, Douglas W, 1984, Financial Intermediation and Delegated Monitoring, Rev. Econ. Stud. 51, 393-414.

Engelberg, Joseph, Pengjie Gao, and Christopher A Parsons, 2012, Friends with money, J. Financ. Econ. 103, 169-188.

Ferreira, M. A., and P. Matos, 2012, Universal Banks and Corporate Control: Evidence from the Global Syndicated Loan Market, Rev. Financ. Stud. 25, 2703-2744.

Firpo, Sergio, 2007, Efficient Semiparametric Estimation of Quantile Treatment Effects, Econometrica 75, 259-276.

Fracassi, Cesare, 2012, Corporate Finance Policies and Social Networks, SSRN Electron. J.

Frank, M., and V. Goyal, 2008, Trade-off and pecking order theories of debt, (in Handb. Corp. Financ. Empir. Corp. Financ., ).

Freeman, Linton C, 1977, A set of measures of centrality based on betweenness, Sociometry $40,35-41$.

Goldman, E, J Rocholl, and J So, 2009, Do Politically Connected Boards Affect Firm Value?, Rev. Financ. Stud. 22, 2331-2360.

Gomes, Armando, and Gordon Phillips, 2012, Why do public firms issue private and public securities?, J. Financ. Intermediation 21, 619-658.

Güner, A Burak, Ulrike Malmendier, and Geoffrey Tate, 2008, Financial Expertise of Directors, J. Financ. Econ. 88, 323/354.

Imbens, Guido W, and Joshua D Angrist, 1994, Identification and Estimation of Local Average Treatment Effects, Econometrica 62, 467-475.

James, C, 1987, Some evidence on the uniqueness of bank loans, J. Financ. Econ. 19, $217-235$.

Kerry Cooper, S., John C. Groth, and William E. Avera, 1985, Liquidity, exchange listing, and common stock performance, J. Econ. Bus. 37, 19-33.

Koenker, Roger, and G Basset, 1978, Regression Quantiles, Econometrica 46, 33 - 50.

Koenker, Roger, and José A. F. Machado, 1999, Goodness of Fit and Related Inference Processes for Quantile Regression, J. Am. Stat. Assoc.

Krakaw, William, and Mark Zenner, 1998, Bankers in the boardroom: good news or bad news, .

Kroszner, R, and Philip E. Strahan, 2001, Bankers on boards: monitoring, conflicts of interest, and lender liability, J. Financ. Econ. 62, 415-452.

Lin, N., 1976, The Foundations of Social Research. (New York: McGraw-Hill, ).

Linck, JS, J Netter, and T Yang, 2008, The determinants of board structure, J. Financ. Econ.

Lorsch, William, and Elizabeth Maciver, 1989, Pawns or potentates: The reality of America's corporate boards. (Harvard Business Press, ). 
Mace, M L, 1971, Directors: Myth and reality, Cambridge MA.

Mansi, Sattar A., William F. Maxwell, and Darius P. Miller, 2010, Analyst forecast characteristics and the cost of debt, Rev. Account. Stud. 16, 116-142.

Maskara, Pankaj K., and Donald J. Mullineaux, 2011, Information asymmetry and selfselection bias in bank loan announcement studies, J. Financ. Econ. 101, 684-694.

Nahapiet, Janine, and Sumantra Ghoshal, 1998, Social capital, intellectual capital, and the organizational advantage, Acad. Manag. Rev. 23, 242-266.

Nohria, N, 1992, Information and Seach in the Creation of New Business Ventures: The Case of the 128 Venture Group, .

Petersen, MA, and R Rajan, 1994, The benefits of lending relationships: Evidence from small business data, J. Finance.

Podolny, J M, 1994, Market Uncertainty and the Social Character of Economic Exchange, Adm. Sci. Q. 39, 458-483.

Rosenbaum, Paul, and Donald B Rubin, 1984, Estimating the Effects Caused by Treatments: Comment [On the Nature and Discovery of Structure], J. Am. Stat. Assoc. 79, $26-28$.

Sabidussi, G, 1966, The centrality index of a graph, Psychometrika 31, 581-603.

Shane, Scott, and Daniel Cable, 2002, Network Ties, Reputation, and the Financing of New Ventures, Manage. Sci. 48, 364-381.

Stuart, Toby E., and Soojin Yim, 2010, Board interlocks and the propensity to be targeted in private equity transactions, J. Financ. Econ. 97, 174-189.

Williamson, Oliver E, 1988, Corporate Finance and Corporate Governance, J. Finance 43, $567-591$. 
A Tables

\begin{tabular}{lccccc}
\hline \hline & count & mean & sd & $\min$ & $\max$ \\
\hline MDRplus1 & 15426 & 0.2073 & 0.1974 & 0.0000 & 1.0000 \\
EBIT/Assets & 15426 & 0.0899 & 0.1114 & -0.4305 & 0.3691 \\
log Market-to-Book & 15426 & 0.3357 & 0.5815 & -0.8672 & 2.0415 \\
Depreciation/Assets & 15426 & 0.0446 & 0.0260 & 0.0063 & 0.1620 \\
log Assets & 15426 & 21.2317 & 1.4912 & 18.1884 & 25.2040 \\
Tangibles Assets & 15426 & 0.2834 & 0.2167 & 0.0135 & 0.8872 \\
R\&D expenses & 15426 & 0.0300 & 0.0497 & 0.0000 & 0.2531 \\
R\&D not declared & 15426 & 0.3495 & 0.4768 & 0.0000 & 1.0000 \\
St Dev Returns & 15426 & 0.0266 & 0.1110 & 0.0000 & 0.8378 \\
Industry Median & 15426 & 0.1659 & 0.1206 & 0.0000 & 0.6948 \\
Presence & 15426 & 0.2671 & 0.4424 & 0.0000 & 1.0000 \\
Board Size & 15426 & 5.9654 & 1.2923 & 1.0000 & 15.0000 \\
Degree & 15426 & 9.6262 & 18.3179 & 0.0000 & 165.0000 \\
Closeness & 15426 & 0.0480 & 0.0812 & 0.0000 & 0.2468 \\
Betweenness & 15426 & 0.0009 & 0.0021 & 0.0000 & 0.0285 \\
IAmm & 12005 & 2.7758 & 0.4608 & 1.5000 & 4.6000 \\
\hline \hline
\end{tabular}

Table 1: Descriptive statistics: Main variables

\begin{tabular}{lccccc}
\hline \hline & count & mean & $\mathrm{sd}$ & $\min$ & $\max$ \\
\hline Inf. Asym. & 12005 & 2.7758 & 0.4608 & 1.5000 & 4.6000 \\
Forecast Error & 12005 & 220.3316 & 1026.2388 & 0.0000 & 5000.0000 \\
Dispersion of Opinion & 12005 & 5.2906 & 24.6292 & 0.0000 & 120.0000 \\
Abn. Ret. Volatility & 12005 & 0.0237 & 0.0118 & 0.0053 & 0.2305 \\
Firm's Age & 12005 & 25.9603 & 19.6885 & 0.0000 & 87.0000 \\
Bid-ask Spread & 12005 & 0.2478 & 4.3880 & 0.0100 & 330.0000 \\
Effective Spread & 12005 & 0.4766 & 0.4117 & -4.7518 & 1.0000 \\
Information Driven Volume & 12005 & 0.4588 & 0.3999 & -1.8368 & 2.0649 \\
Proportional Spread & 12005 & 0.9961 & 0.1242 & -0.9217 & 6.6504 \\
Amihud & 12005 & 0.0004 & 0.0064 & -0.4050 & 0.2938 \\
Amivest & 12005 & 665743.1296 & 11956781.8291 & 4.1017 & $8.4887 \mathrm{e}+08$ \\
\hline \hline
\end{tabular}

Table 2: Descriptive statistics: Information Asymmetry Index and proxies used. 


\begin{tabular}{|c|c|c|c|}
\hline & (1) & $(2)$ & (3) \\
\hline \multicolumn{4}{|l|}{ main } \\
\hline EBIT/Assets & $\begin{array}{c}-0.277^{* * *} \\
(-15.32)\end{array}$ & $\begin{array}{c}-0.165^{* * *} \\
(-8.82)\end{array}$ & $\begin{array}{c}-0.252^{* * *} \\
(-14.11)\end{array}$ \\
\hline log Market-to-Book & $\begin{array}{c}-0.122^{* * *} \\
(-41.22)\end{array}$ & $\begin{array}{c}-0.0806^{* * *} \\
(-16.44)\end{array}$ & $\begin{array}{c}-0.120^{* * *} \\
(-41.18)\end{array}$ \\
\hline Depreciation/Assets & $\begin{array}{c}-0.432^{* * *} \\
(-6.34)\end{array}$ & $\begin{array}{c}-0.346^{* *} \\
(-2.52)\end{array}$ & $\begin{array}{c}-0.464^{* * *} \\
(-6.99)\end{array}$ \\
\hline $\log$ Assets & $\begin{array}{c}0.0193^{* * *} \\
(21.10)\end{array}$ & $\begin{array}{c}0.0335^{* * *} \\
(5.88)\end{array}$ & $\begin{array}{c}0.0186^{* * *} \\
(20.55)\end{array}$ \\
\hline Tangibles Assets & $\begin{array}{c}0.0851^{* * *} \\
(10.06)\end{array}$ & $\begin{array}{c}0.0777^{* *} \\
(2.24)\end{array}$ & $\begin{array}{c}0.0868^{* * *} \\
(10.46)\end{array}$ \\
\hline$R \& D$ expenses & $\begin{array}{c}-0.261^{* * *} \\
(-8.00)\end{array}$ & $\begin{array}{c}-0.189^{* *} \\
(-2.30)\end{array}$ & $\begin{array}{c}-0.236^{* * *} \\
(-7.36)\end{array}$ \\
\hline R\&D not declared & $\begin{array}{c}0.0209^{* * *} \\
\quad(6.71)\end{array}$ & $\begin{array}{c}-0.0100 \\
(-0.82)\end{array}$ & $\begin{array}{c}0.0197^{* * *} \\
\quad(6.44)\end{array}$ \\
\hline St Dev Returns & $\begin{array}{c}0.0399^{* * *} \\
(2.65)\end{array}$ & $\begin{array}{c}0.0502^{*} \\
(1.86)\end{array}$ & $\begin{array}{c}0.0309^{* *} \\
(2.08)\end{array}$ \\
\hline Industry Median & $\begin{array}{c}0.253^{* * *} \\
(17.51)\end{array}$ & $\begin{array}{c}0.168^{* * *} \\
(4.60)\end{array}$ & $\begin{array}{c}0.246^{* * *} \\
(17.46)\end{array}$ \\
\hline Presence & $\begin{array}{c}-0.00629^{* *} \\
(-2.16)\end{array}$ & $\begin{array}{c}-0.00253 \\
(-0.57)\end{array}$ & $\begin{array}{c}0.226^{* * *} \\
(38.40)\end{array}$ \\
\hline Constant & $\begin{array}{c}-0.108^{* * *} \\
(-5.03) \\
\end{array}$ & $\begin{array}{c}-0.508^{* * *} \\
(-4.22) \\
\end{array}$ & $\begin{array}{c}-0.271^{* * *} \\
(-13.02) \\
\end{array}$ \\
\hline Year F.E. & Yes & Yes & Yes \\
\hline Firm F.E. & No & No & Yes \\
\hline Observations & 15426 & 15426 & 15426 \\
\hline
\end{tabular}

Table 3: Presence of banker-director. We test hypothesis 1 by running the following regression on equation 1 where the dependent variable, $M D R_{t+1}$ is the debt level, measured as the ratio of total debt to the sum of market capitalization and total debt, is regressed on (EBIT/TA) EBIT over total assets; the log of market-to-book ratio; (Depreciation/Asssets) the log of total assets as a measure of size; Tangible Assets is the ratio of fixed to total assets as a measure of asset tangibility; the ratio of $\mathrm{R} \& \mathrm{D}$ expenditure to total assets as a proxy for asset specificity (missing R\&D data is set to zero); and the standard deviation of total returns index as proxy for firm volatility. We also control for year and industry median effects. Presence denotes the presence of a banker-director on the Board. The first two columns are estimated with OLS, while the third presents the average treatment effects estimates, where Board Size is used as instrument. All variables are winsorized at $1 \%$ level. Robust Standard errors. 


\begin{tabular}{|c|c|c|c|c|c|c|}
\hline & $(1)$ & $(2)$ & $(3)$ & $(4)$ & $(5)$ & $(6)$ \\
\hline EBIT/Assets & $\begin{array}{c}-0.295^{* * *} \\
(-13.68)\end{array}$ & $\begin{array}{c}-0.300^{* * *} \\
(-12.72)\end{array}$ & $\begin{array}{c}-0.297^{* * *} \\
(-12.87)\end{array}$ & $\begin{array}{c}-0.166^{* * *} \\
(-9.78)\end{array}$ & $\begin{array}{c}-0.172^{* * *} \\
(-9.30)\end{array}$ & $\begin{array}{c}-0.171^{* * *} \\
(-9.46)\end{array}$ \\
\hline log Market-to-Book & $\begin{array}{c}-0.123^{* * *} \\
(-36.85)\end{array}$ & $\begin{array}{c}-0.123^{* * *} \\
(-35.83)\end{array}$ & $\begin{array}{c}-0.122^{* * *} \\
(-34.12)\end{array}$ & $\begin{array}{c}-0.0841^{* * *} \\
(-21.91)\end{array}$ & $\begin{array}{c}-0.0815^{* * *} \\
(-17.96)\end{array}$ & $\begin{array}{c}-0.0865^{* * *} \\
(-20.96)\end{array}$ \\
\hline Depreciation/Assets & $\begin{array}{c}-0.544^{* * *} \\
(-5.78)\end{array}$ & $\begin{array}{c}-0.534^{* * *} \\
(-5.70)\end{array}$ & $\begin{array}{c}-0.583^{* * *} \\
(-5.07)\end{array}$ & $\begin{array}{c}-0.414^{* * *} \\
(-3.76)\end{array}$ & $\begin{array}{c}-0.426^{* * *} \\
(-3.61)\end{array}$ & $\begin{array}{c}-0.433^{* * *} \\
(-3.75)\end{array}$ \\
\hline $\log$ Assets & $\begin{array}{c}0.0000313 \\
\quad(0.00)\end{array}$ & $\begin{array}{c}-0.00367 \\
(-0.30)\end{array}$ & $\begin{array}{c}-0.00274 \\
(-0.23)\end{array}$ & $\begin{array}{c}0.0237^{* * *} \\
(3.75)\end{array}$ & $\begin{array}{c}0.0230^{* * *} \\
(3.27)\end{array}$ & $\begin{array}{c}0.0281^{* * *} \\
(6.13)\end{array}$ \\
\hline Tangibles Assets & $\begin{array}{c}0.0999^{* * *} \\
(8.42)\end{array}$ & $\begin{array}{c}0.101^{* * *} \\
(7.94)\end{array}$ & $\begin{array}{c}0.106^{* * *} \\
(6.99)\end{array}$ & $\begin{array}{c}0.0832^{* * *} \\
(3.59)\end{array}$ & $\begin{array}{c}0.0735^{* * *} \\
(2.87)\end{array}$ & $\begin{array}{c}0.0987^{* * *} \\
(3.89)\end{array}$ \\
\hline $\mathrm{R} \& \mathrm{D}$ expenses & $\begin{array}{c}-0.212^{* * *} \\
(-5.00)\end{array}$ & $\begin{array}{c}-0.198^{* * *} \\
(-4.09)\end{array}$ & $\begin{array}{c}-0.229^{* * *} \\
(-5.62)\end{array}$ & $\begin{array}{c}-0.302^{* * *} \\
(-3.30)\end{array}$ & $\begin{array}{c}-0.340^{* * *} \\
(-3.00)\end{array}$ & $\begin{array}{c}-0.278^{* * *} \\
(-3.12)\end{array}$ \\
\hline $\mathrm{R} \& \mathrm{D}$ not declared & $\begin{array}{c}0.0257^{* * *} \\
\quad(6.09)\end{array}$ & $\begin{array}{c}0.0287^{* * *} \\
\quad(5.23)\end{array}$ & $\begin{array}{c}0.0232^{* * *} \\
\quad(5.85)\end{array}$ & $\begin{array}{c}-0.0206^{* *} \\
(-2.06)\end{array}$ & $\begin{array}{c}-0.0166^{*} \\
(-1.82)\end{array}$ & $\begin{array}{c}-0.0246^{* *} \\
(-2.03)\end{array}$ \\
\hline St Dev Returns & $\begin{array}{c}0.0158 \\
(0.75)\end{array}$ & $\begin{array}{c}0.0124 \\
(0.54)\end{array}$ & $\begin{array}{r}0.0137 \\
(0.59)\end{array}$ & $\begin{array}{c}0.0580^{* * *} \\
(2.73)\end{array}$ & $\begin{array}{c}0.0608^{* * *} \\
(2.61)\end{array}$ & $\begin{array}{c}0.0503^{* *} \\
(2.37)\end{array}$ \\
\hline Industry Median & $\begin{array}{c}0.217^{* * *} \\
(8.84)\end{array}$ & $\begin{array}{c}0.213^{* * *} \\
(7.86)\end{array}$ & $\begin{array}{c}0.210^{* * *} \\
(7.16)\end{array}$ & & & \\
\hline Degree & $\begin{array}{c}0.00444^{*} \\
(1.90)\end{array}$ & & & $\begin{array}{c}0.00363^{*} \\
(1.76)\end{array}$ & & \\
\hline Closeness & & $\begin{array}{l}1.197^{*} \\
(1.83)\end{array}$ & & & $\begin{array}{l}1.132^{*} \\
(1.66)\end{array}$ & \\
\hline Betweenness & & & $\begin{array}{l}53.01^{*} \\
(1.77)\end{array}$ & & & $\begin{array}{l}36.40^{*} \\
(1.65)\end{array}$ \\
\hline Constant & $\begin{array}{l}0.170 \\
(0.82) \\
\end{array}$ & $\begin{array}{l}0.236 \\
(0.94) \\
\end{array}$ & $\begin{array}{l}0.224 \\
(0.89) \\
\end{array}$ & & & \\
\hline Year F.E. & Yes & Yes & Yes & Yes & Yes & Yes \\
\hline Firm F.E. & No & No & No & Yes & Yes & Yes \\
\hline Observations & 15426 & 15426 & 15426 & 15229 & 15229 & 15229 \\
\hline
\end{tabular}

Table 4: Connectedness of banker-directors. We test hypothesis 2 by running the following regression on equation 1 where the dependent variable, $M D R_{t+1}$ is the debt level, measured as the ratio of total debt to the sum of market capitalization and total debt, is regressed on (EBIT/TA) EBIT over total assets; the log of market-to-book ratio; (Depreciation/Asssets) the log of total assets as a measure of size; Tangible Assets is the ratio of fixed to total assets as a measure of asset tangibility; the ratio of $\mathrm{R} \& \mathrm{D}$ expenditure to total assets as a proxy for asset specificity (missing R\&D data is set to zero); , and the standard deviation of total returns index as proxy for firm volatility. Degree, Closeness and Betweenness denote the respective connectedness measures of a banker-director on the Board. All estimates include Board Size as instrument and year fixed effects. The last three columns add firm fixed effects. We also control for year-industry median effects. All variables are winsorized at $1 \%$ level. Robust Standard errors. 


\begin{tabular}{lccc}
\hline \hline & $(1)$ & $(2)$ & $(3)$ \\
\hline Degree & $0.00363^{*}$ & $0.00419^{*}$ & $0.0140^{*}$ \\
& $(1.76)$ & $(1.79)$ & $(1.70)$ \\
Closeness & $1.132^{*}$ & 2.585 & 5.300 \\
& $(1.66)$ & $(1.45)$ & $(1.17)$ \\
Betweenness & $36.40^{*}$ & 46.88 & 608.1 \\
& $(1.65)$ & $(1.54)$ & $(0.30)$ \\
\hline Year F.E. & Yes & Yes & Yes \\
Firm F.E. & Yes & Yes & Yes \\
\hline Observations & 15229 & 15229 & 11079 \\
\hline \hline$t$ statistics in parentheses & & \\
$*$ & \\
& &
\end{tabular}

Table 5: Connectedness of banker-directors. We test hypothesis 2 by running the following regression on equation 11 where the dependent variable, $M D R_{t+1}$ is the debt level, measured as the ratio of total debt to the sum of market capitalization and total debt, is regressed on different measures of connectedness: Degree, Closeness and Betweenness. In the first column, the value for the firm is given by the value of the most connected banker on the board, where a firm with no banker is given a value of 0 . In the second column, the value of board connectedness is measured as the maximum connectedness of the individual director (excluding bankers). In the third column, we repeat the latter variable but exclude firms that have banker-directors. All estimates include the controls used in the previous tables, Board Size as instrument, and year and firm fixed effects. We also control for year-industry median effects. All variables are winsorized at $1 \%$ level. Robust Standard errors. 


\begin{tabular}{|c|c|c|c|c|c|}
\hline & (1) & $(2)$ & (3) & (4) & (5) \\
\hline EBIT/Assets & $\begin{array}{c}-0.152^{* * *} \\
(-7.35)\end{array}$ & $\begin{array}{c}-0.207^{* * *} \\
(-4.69)\end{array}$ & $\begin{array}{c}-0.171^{* * *} \\
(-7.40)\end{array}$ & $\begin{array}{c}-0.197^{* * *} \\
(-5.37)\end{array}$ & $\begin{array}{c}-0.171^{* * *} \\
(-6.92)\end{array}$ \\
\hline log Market-to-Book & $\begin{array}{c}-0.0924 * * * \\
(-16.99)\end{array}$ & $\begin{array}{c}-0.0880^{* * *} \\
(-9.96)\end{array}$ & $\begin{array}{c}-0.0953^{* * *} \\
(-18.51)\end{array}$ & $\begin{array}{c}-0.0910^{* * *} \\
(-13.20)\end{array}$ & $\begin{array}{c}-0.0954^{* * *} \\
(-17.69)\end{array}$ \\
\hline Depreciation/Assets & $\begin{array}{c}-0.352^{* *} \\
(-2.06)\end{array}$ & $\begin{array}{c}-0.541^{* *} \\
(-2.40)\end{array}$ & $\begin{array}{c}-0.522^{* * *} \\
(-3.29)\end{array}$ & $\begin{array}{c}-0.603^{* * *} \\
(-2.76)\end{array}$ & $\begin{array}{c}-0.432^{* * *} \\
(-2.73)\end{array}$ \\
\hline $\log$ Assets & $\begin{array}{c}0.0341^{* * *} \\
(5.54)\end{array}$ & $\begin{array}{c}0.0215^{*} \\
(1.90)\end{array}$ & $\begin{array}{c}0.0181^{*} \\
(1.90)\end{array}$ & $\begin{array}{c}0.0140 \\
(0.97)\end{array}$ & $\begin{array}{c}0.0295^{* * *} \\
(5.35)\end{array}$ \\
\hline Tangibles Assets & $\begin{array}{c}0.0701^{*} \\
(1.77)\end{array}$ & $\begin{array}{c}0.0444 \\
(0.88)\end{array}$ & $\begin{array}{c}0.0654^{* *} \\
(2.00)\end{array}$ & $\begin{array}{c}0.0499 \\
(1.11)\end{array}$ & $\begin{array}{c}0.0703^{* *} \\
(2.06)\end{array}$ \\
\hline R\&D expenses & $\begin{array}{l}-0.163 \\
(-1.64)\end{array}$ & $\begin{array}{c}-0.470^{*} \\
(-1.87)\end{array}$ & $\begin{array}{c}-0.320^{* *} \\
(-2.44)\end{array}$ & $\begin{array}{c}-0.485^{*} \\
(-1.95)\end{array}$ & $\begin{array}{c}-0.239^{* *} \\
(-2.21)\end{array}$ \\
\hline R\&D not declared & $\begin{array}{c}-0.00102 \\
(-0.08)\end{array}$ & $\begin{array}{c}-0.0369 \\
(-1.36)\end{array}$ & $\begin{array}{c}-0.0292^{*} \\
(-1.65)\end{array}$ & $\begin{array}{c}-0.0332 \\
(-1.40)\end{array}$ & $\begin{array}{c}-0.0255 \\
(-1.61)\end{array}$ \\
\hline St Dev Returns & $\begin{array}{c}0.0438^{* *} \\
(1.99)\end{array}$ & $\begin{array}{c}0.0470 \\
(1.21)\end{array}$ & $\begin{array}{c}0.0428 \\
(1.50)\end{array}$ & $\begin{array}{c}0.0346 \\
(0.96)\end{array}$ & $\begin{array}{c}0.0674^{*} \\
(1.92)\end{array}$ \\
\hline Inf. Asym. & $\begin{array}{c}0.0138^{* * *} \\
(3.46)\end{array}$ & $\begin{array}{c}-0.119 * \\
(-1.66)\end{array}$ & $\begin{array}{c}-0.0682^{* *} \\
(-2.18)\end{array}$ & $\begin{array}{c}-0.0949^{*} \\
(-1.85)\end{array}$ & $\begin{array}{c}-0.0642^{*} \\
(-1.92)\end{array}$ \\
\hline Presence & & $\begin{array}{l}-0.732 \\
(-1.26)\end{array}$ & & & \\
\hline Degree & & & $\begin{array}{c}-0.0149^{* *} \\
(-2.40)\end{array}$ & & \\
\hline Closeness & & & & $\begin{array}{l}-3.108 \\
(-1.52)\end{array}$ & \\
\hline Betweenness & & & & & $\begin{array}{c}-181.7^{* *} \\
(-2.12)\end{array}$ \\
\hline interation & & $\begin{array}{c}0.441^{*} \\
(1.81)\end{array}$ & $\begin{array}{c}0.00768^{* *} \\
(2.56)\end{array}$ & $\begin{array}{c}2.008^{* *} \\
(2.08)\end{array}$ & $\begin{array}{c}84.44^{* *} \\
(2.26)\end{array}$ \\
\hline Constant & $\begin{array}{c}-0.529^{* * *} \\
(-4.06)\end{array}$ & & & & \\
\hline Years & Yes & Yes & Yes & Yes & Yes \\
\hline Observations & 12500 & 11760 & 11760 & 11760 & 11760 \\
\hline
\end{tabular}

$t$ statistics in parentheses

* $\mathrm{p}_{\mathrm{i}} 0.1,{ }^{* *} \mathrm{p}_{\mathrm{j}} 0.05, * * * \mathrm{p}_{\mathrm{j}} 0.01$

Table 6: Interaction information opacity proxy and Bankers' Presence and connectedness. We test hypothesis 3 by running the following regression on equation 2 where the dependent variable, $M D R_{t+1}$ is the debt level, measured as the ratio of total debt to the sum of market capitalization and total debt, is regressed on (EBIT/TA) EBIT over total assets; the log of market-to-book ratio; (Depreciation/Asssets) the log of total assets as a measure of size; Tangible Assets is the ratio of fixed to total assets as a measure of asset tangibility; the ratio of $R \& D$ expenditure to total assets as a proxy for asset specificity (missing R\&D data is set to zero); , and the standard deviation of total returns index as proxy for firm volatility. Inf. Asym. is a proxy for information asymmetry based on Maskara and Mullineaux (2011). Degree, Closeness and Betweenness denote the respective connectedness measures of a banker-director on the Board. All estimates include Board Size as instrument and year fixed effects. We also control for year and industry median effects. All variables are winsorized at 1\% level. Robust Standard errors. 


\begin{tabular}{lcccc}
\hline & Coefficient & Std. Err. & \multicolumn{2}{c}{$90 \%$ Conf. Int. } \\
\hline $\mathrm{q} 10$ & & & & \\
$(1$ vs 0$)$ & 0.0043846 & 0.0022729 & 0.000646 & 0.0081232 \\
\hline $\mathrm{q} 25$ & & & & \\
$(1$ vs 0) & 0.0156265 & 0.0041548 & 0.0087925 & 0.0224606 \\
\hline $\mathrm{q} 50$ & & & & \\
$(1$ vs 0$)$ & .01082 & .0045298 & 0.0033692 & 0.0182708 \\
\hline $\mathrm{q} 75$ & & & & \\
$(1$ vs 0$)$ & -0.0043977 & 0.0069998 & -0.0159113 & 0.0071159 \\
\hline $\mathrm{q} 90$ & & & & \\
$(1$ vs 0$)$ & -0.0034469 & 0.0110712 & -0.0216574 & 0.0147636 \\
\hline \hline
\end{tabular}

Table 7: Quantile treatment effects: Effect of the presence of banker-director (1) vs no banker $(0)$ on debt level of firms. We test hypothesis 4 by running a quantile treatment effects regression on equation 1 as in Cattaneo (2010). The dependent variable, $M D R_{t+1}$ is the debt level, measured as the ratio of total debt to the sum of market capitalization and total debt, is regressed on (EBIT/TA) EBIT over total assets; the log of market-to-book ratio; (Depreciation/Asssets) the log of total assets as a measure of size; Tangible Assets is the ratio of fixed to total assets as a measure of asset tangibility; the ratio of $\mathrm{R} \& \mathrm{D}$ expenditure to total assets as a proxy for asset specificity (missing R\&D data is set to zero); , and the standard deviation of total returns index as proxy for firm volatility. All estimates include Board Size as instrument and year fixed effects. We also control for year and industry median effects. All variables are winsorized at $1 \%$ level. Robust Standard errors.

\begin{tabular}{lcccc}
\hline \hline & Coefficient & Std. Err. & \multicolumn{2}{c}{$90 \%$ Conf. Int. } \\
\hline $\mathrm{q} 15$ & & & & \\
$(1$ vs 0$)$ & 0.0062865 & 0.0026585 & 0.0019135 & 0.0106594 \\
$(2$ vs 0$)$ & 0.0146297 & 0.0074593 & 0.0023603 & 0.0268991 \\
\hline $\mathrm{q} 25$ & & & & \\
$(1$ vs 0$)$ & 0.0093877 & 0.0042583 & 0.0023833 & 0.016392 \\
$(2$ vs 0$)$ & 0.016726 & 0.0060698 & 0.0067421 & 0.0267099 \\
\hline $\mathrm{q} 50$ & & & & \\
$(1$ vs 0$)$ & 0.0045433 & 0.0047509 & -0.0032712 & 0.0123579 \\
$(2$ vs 0$)$ & 0.0103283 & 0.0068571 & -0.0009506 & 0.0216073 \\
\hline $\mathrm{q} 75$ & & & & \\
$(1$ vs 0$)$ & -0.0032754 & 0.0077939 & -0.0160953 & 0.0095445 \\
$(2$ vs 0$)$ & -0.0047175 & 0.0092802 & -0.0199821 & 0.0105471 \\
\hline $\mathrm{q} 90$ & & & & \\
$(1$ vs 0$)$ & 0.0004884 & 0.0158953 & -0.0256571 & 0.0266339 \\
$(2$ vs 0) & -0.0047172 & 0.0199636 & -0.0375544 & 0.0281201 \\
\hline \hline
\end{tabular}

Table 8: Quantile multi valued treatment effects: Effect of the connectedness of banker-director on debt level of firms. Weakly connected banker-director (1) vs no Banker (0); Highly connected banker-directors (2) vs no Banker (0). We test hypothesis 5 by running a quantile treatment effects regression on equation 1 as in Cattaneo (2010). The dependent variable, $M D R_{t+1}$ is the debt level, measured as the ratio of total debt to the sum of market capitalization and total debt, is regressed on (EBIT/TA) EBIT over total assets; the log of market-to-book ratio; (Depreciation/Asssets) the $\log$ of total assets as a measure of size; Tangible Assets is the ratio of fixed to total assets as a measure of asset tangibility; the ratio of R\&D expenditure to total assets as a proxy for asset specificity (missing $\mathrm{R} \& \mathrm{D}$ data is set to zero); , and the standard deviation of total returns index as proxy for firm volatility. All estimates include Board Size as instrument and year fixed effects. We also control for year and industry median effects. All variables are winsorized at $1 \%$ level. Robust Standard errors. 


\section{B Figures}

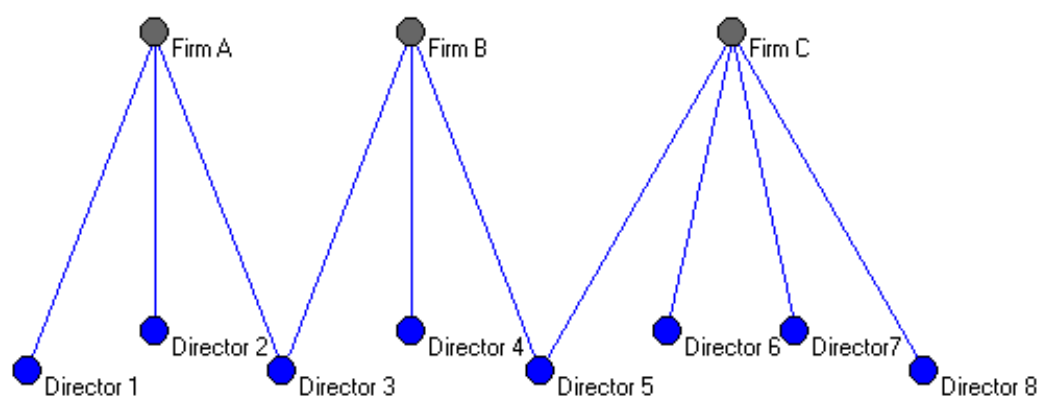

Figure 1: Example of a network with 3 firms and 8 directors.

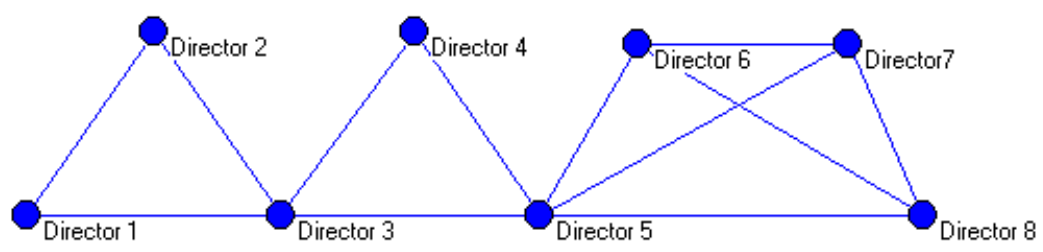

Figure 2: Projection of the example network represented in figure 1 onto the space of Directors.

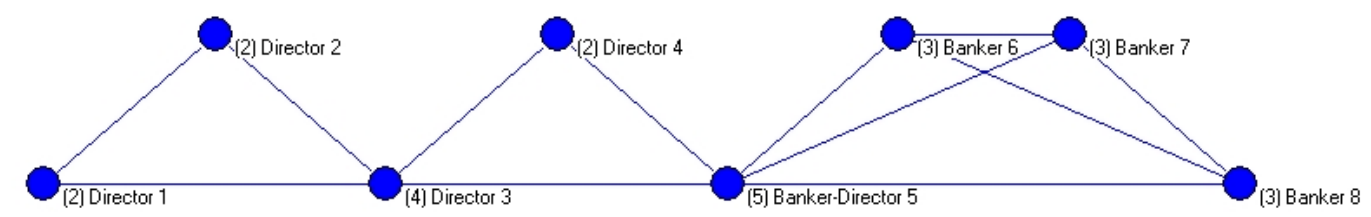

Figure 3: Going back to the firm dimension: example using degree 


\section{INOVA}

\section{NOVA}

School

of Business

\& Economics

Shaping

powerful

minds

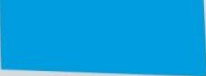

Nova School of Business and Economics

Faculdade de Economia

Universidade Nova de Lisboa

Campus de Campolide 1099-032 Lisboa PORTUGAL

Tel.: +351213801600

www.novasbe.pt 